\title{
PENGARUH PENDINGINAN CEPAT TERHADAP LAJU KOROSI HASIL PENGELASAN BAJA AISI 1045
}

\author{
Lukito Dwi Yuono ${ }^{1 *}$, Untung Surya Dharma ${ }^{2}$ \\ Jurusan Teknik Mesin, Fakultas Teknik, Universitas Muhammadiyah Metro ${ }^{1,2}$, \\ Jl. Ki Hajar Dewantara 15 A Metro, Lampung \\ e-mail ; lukitody1@gmail.com¹, untungsdh@yahoo.co.id²
}

\begin{abstract}
Abstrak
Pada beberapa kasus, sering ditemukan kerusakan pada rangka kendaraan terutama masalah korosi pada sambungan pengelasan. Masalah ini dapat membahayakan keselamatan pengendara karena korosi akan mengurangi kekuatan sambungan pada rangka tersebut. Tujuan dari penelitian ini adalah untuk mengetahui pengaruh pendinginan cepat terhadap laju korosi hasil pengelasan baja karbon sedang (baja AISI 1045). Penelitian ini menggunakan metode eksperimen nyata. Spesimen yang sudah disambung menggunakan las listrik diberikan proses heat treatment yakni pendinginan dengan udara, pendinginan dengan oli, dan pendinginan dengan air. Kemudian seluruh spesimen dilakukan uji korosi selama 8 jam. Hasil dari data dan perhitungan laju korosi menunjukkan bahwa nilai laju korosi paling tinggi adalah pengelasan dengan media pendingin udara yaitu senilai 31508.1 mpy atau 31.5081 inch/tahun, nilai laju korosi terendah adalah pengelasan dengan media pendingin air yaitu 10228.71 mpy atau 10.22871 inch/tahun. Hal ini mengindikasikan bahwa PWHT (post welding heat threatment) memiliki pengaruh besar dalam usaha penghambatan laju korosi.
\end{abstract}

Kata kunci: Baja AISI 1045, korosi, media pendingin, SMAW.

\section{Pendahuluan}

Korosi (corrosion) merupakan salah satu penyebab kerusakan pada material logam termasuk juga pada pengelasan logam dimana terjadi penipisan atau pengurangan material yang disebabkan oleh lingkungan. Material logam akan menghadapi berbagai macam lingkungan, baik selama tahapan pembuatan, pemindahan, dan peyimpanan, maupun ketika kelak harus menjalankan tugas sehari-hari. Perubahan kecil saja pada lingkungan, laju aliran, dan adanya polusi dapat mengubah sifat dan ketahanan korosi secara radikal. Untuk mengurangi terjadinya korosi ini maka perlu adanya perubahan struktur mikro dari sambungan las yaitu dengan cara memberi perlakuan panas pasca pengelasan (post weld heat treatment /PWHT)[1].

Proses perlakuan panas (heat treatment) terdiri dari dari tiga tahap yaitu; heating, holding, dan cooling, dimana ketiga tahap tersebut akan mempengaruhi hasil proses heat treatment. Faktor utama yang sangat mempengaruhi perubahan sifat mekanik ini adalah perubahan phase. Struktur dari phase tersebut sangat dipengaruhi oleh temperatur pemanasan (heating), lama pemanasan (holding time), dan kecepatan pendinginan (cooling rate)[2].

Dari sekian banyak jenis logam, logam baja adalah jenis logam yang paling banyak digunakan dalam pemenuhan kebutuhan manusia. Dan dari berbagai klasifikasi baja, baja dengan kandungan karbon sedang adalah baja yang sering diberi perlakuan panas dengan cara pendinginan cepat (quenching), salah satu jenisnya adalah baja AISI 1045. Baja AISI 1045 dalam pengaplikasiannya adalah sebagai bahan pembuat rangka kendaraan yang tentu saja penyambungannya sebagian besar menggunakan metode pengelasan.

$$
\text { Pada beberapa kasus, sering }
$$
ditemukan kerusakan pada rangka 
kendaraan terutama masalah korosi pada sambungan pengelasan. Masalah ini dapat membahayakan keselamatan pengendara karena korosi akan mengurangi kekuatan sambungan pada rangka tersebut. Dari beberapa ulasan tersebut, maka perlu dilakukan penelitian tentang pengaruh pendinginan cepat terhadap laju korosi hasil sambungan las pada baja AISI 1045.

\section{Tinjauan Teoritis}

\section{Pengelasan}

Pengelasan

merupakan

penyambungan dua bahan atau lebih yang didasarkan pada prinsip-prinsip proses difusi, sehingga terjadi penyatuan bagian bahan yang disambung. Kelebihan sambungan las adalah konstruksi ringan, dapat menahan kekuatan yang tinggi, mudah pelaksanaannya, serta cukup ekonomis. Namun kelemahan yang paling utama adalah terjadinya perubahan struktur mikro bahan yang dilas, sehingga terjadi perubahan sifat fisik maupun mekanis dari bahan yang dilas. Perkembangan teknologi pengelasan logam memberikan kemudahan umat manusia dalam menjalankan kehidupannya. Saat ini kemajuan ilmu pengetahuan di bidang elektronik melalui penelitian yang melihat karakteristik atom, mempunyai kontribusi yang sangat besar terhadap penemuan material baru dan sekaligus bagaimanakah menyambungnya.

Jauh sebelumnya, penyambungan logam dilakukan dengan memanasi dua buah logam dan menyatukannya secara bersama. Logam yang menyatu tersebut dikenal dengan istilah fusion. Las listrik merupakan salah satu yang menggunakan prinsip tersebut.

Pada zaman sekarang pemanasan logam yang akan disambung berasal dari pembakaran gas atau arus listrik. Beberapa gas dapat digunakan, tetapi yang sangat popular adalah gas acetylene yang lebih dikenal dengan gas karbit. Selama pengelasan, gas acetylene dicampur dengan gas oksigen murni. Kombinasi campuran gas tersebut memproduksi panas yang paling tinggi diantara campuran gas lain.
Cara lain yang paling utama digunakan untuk memanasi logam yang dilas adalah arus listrik. Arus listrik dibangkitkan oleh generator dan dialirkan melalui kabel ke sebuah alat yang menjepit elektroda diujungnya, yaitu suatu logam batangan yang dapat menghantarkan listrik dengan baik. Ketika arus listrik dialirkan, elektroda disentuhkan ke benda kerja dan kemudian ditarik ke belakang sedikit, arus listrik tetap mengalir melalui celah sempit antara ujung elektroda dengan benda kerja. Arus yang mengalir ini dinamakan busur (arc) yang dapat mencairkan logam. Terkadang dua logam yang disambung dapat menyatu secara langsung, namun terkadang masih diperlukan bahan tambahan lain agar deposit logam lasan terbentuk dengan baik, bahan tersebut disebut bahan tambah (filler metal). Filler metal biasanya berbentuk batangan, sehingga biasa dinamakan welding rod (Elektroda las). Pada proses las, welding rod dibenamkan ke dalam cairan logam yang tertampung dalam suatu cekungan yang disebut welding pool dan secara bersama-sama membentuk deposit logam lasan, cara seperti ini dinamakan Las Listrik atau SMAW (Shielded metal Arch welding)[2], lihat gambar 1 .

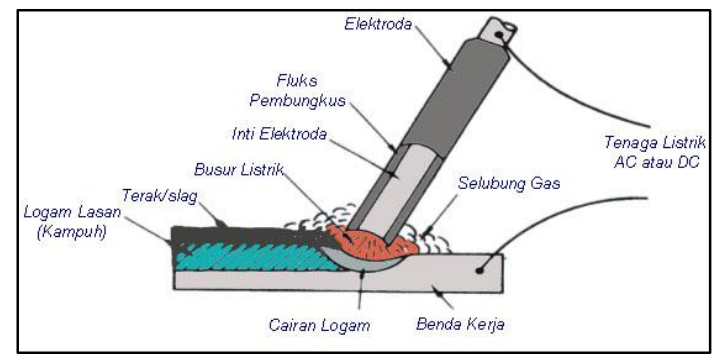

Gambar 1. Prinsip Kerja Las Listrik

Sebagian besar logam akan berkarat (korosi) ketika bersentuan dengan udara atau uap air, sebagai contoh adalah logam besi mempunyai karat, dan alumunium mempunyai lapisan putih di permukaannya. Pemanasan dapat mempercepat proses korosi tersebut. Jika karat, kotoran, atau material lain ikut tercampur ke dalam cairan logam lasan dapat menyebabkan kekeroposan deposit logam lasan yang 
terbentuk sehingga menyebabkan cacat pada sambungan las [5].

\section{Reaksi Kimia Selama Proses Las}

Dalam proses LSW bagian dari logam yang dilas harus dipanasi sampai mencair. Pemanasan logam dengan temperatur yang sangat tinggi ini dapat megakibatkan terjadinya reaksi kimia antara logam tersebut dengan Oksigen dan Nitrogen yang ada dalam udara. Jika selama proses las cairan logam las (welding pool) tidak dilindungi dari pengaruh udara, maka logam akan bereaksi dengan Oksigen dan Nitrogen membentuk Oxides dan Nitrides yang dapat menyebabkan logam tersebut menjadi getas dan keropos karena adanya kotoran (slag inclutions), sedangkan kandungan unsur Karbon dalam logam akan membentuk gas $\mathrm{CO}$ yang dapat mengakibatkan adanya rongga dalam logam las (caviety). Reaksi kimia lainnyapun bisa terjadi dalam cairan logam las (welding pool). Gas Hydrogen dan uap air juga dapat menyebabkan cacat las (welding defect). Hydrogen yang bereaksi dengan Oxides yang ada dalam logam dasar dapat menyebabkan terjadinya uap yang mengakibatkan terjadnya porositas pada logam lasan.

\section{Perubahan Sifat Logam Setelah Proses Las}

Pencairan logam saat pengelasan menyebabkan adanya perubahan fasa logam dari padat hingga mencair. Ketika logam cair mulai membeku akibat pendinginan cepat, maka akan terjadi perubahan struktur mikro dalam deposit logam las dan logam dasar yang terkena pengaruh panas (Heat affected zone/HAZ). Struktur mikro dalam logam lasan biasanya berbentuk columnar, sedangkan pada daerah HAZ terdapat perubahan yang sangat bervariasi. Sebagai contoh, pengelasan baja karbon tinggi sebelumnya berbentuk pearlite, maka seelah pengelasan struktur mikronya tidak hanya pearlite, tetapi juga terdapat bainite dan martensite. Perubahan ini mengakibatkan perubahan pula sifat-sifat logam dari sebelumnya.
Struktur mikro pearlite memiliki sifat liat dan tidak keras, sebaliknya martensite mempunyai sifat keras dan getas. Biasanya keretakan sambungan las berasal dari struktur mikro ini. Gambar 2 mendeskripsikan distribusi temperatur pada logam dasar yang sangat bervariasi telah menyebabkan berbagai macam perlakuan panas terhadap daerah HAZ logam tersebut. Logam lasan mengalami pemanasan hingga termperatur $1500^{\circ} \mathrm{C}$ dan daerah $\mathrm{HAZ}$ bervariasi mulai $200^{\circ} \mathrm{C}$ hingga $1100^{\circ} \mathrm{C}$ (Gambar 3). Temperatur $1500^{\circ} \mathrm{C}$ pada logam lasan menyebabkan pencairan dan ketika membeku membentk struktur mikro columnar. Temperatur $200^{\circ} \mathrm{C}$ hingga $1100^{\circ} \mathrm{C}$ menyebabkan perubahan struktur mikro pada logam dasar baik ukuran maupun bentuknya [4].

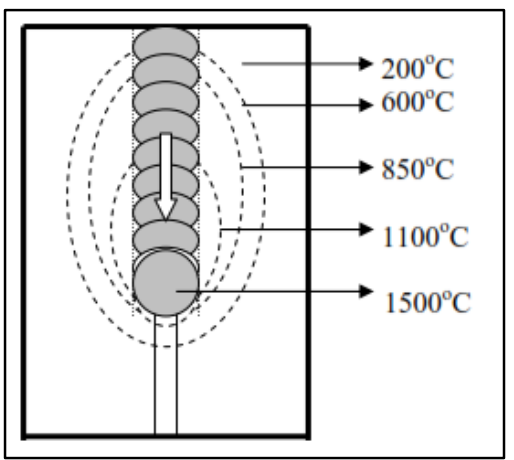

Gambar 2. Distribusi Temperatur Saat Pengelasan

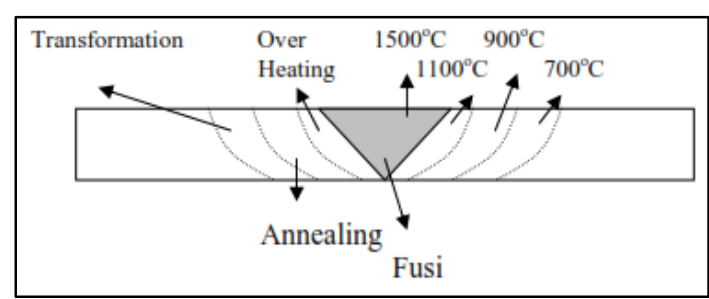

Gambar 3. Perlakuan Panas Logam Las

\section{Ruang Lingkup Pekerjaan Las}

Industri manufaktur tidak dapat terlepas dari penyambungan logam. Penyambungan logam dilakukan dengan berbagai tujuan, diantaranya adalah untuk membuat suatu barang yang tidak mungkin dilakukan dengan teknik lain, memudahkan pekerjaan, serta dapat menekan biaya produksi. Proses penyambungan logam yang banyak digunakan dalam industri manufaktur adalah las. Pengelasan logam 
merupakan pilihan yang cukup tepat. Pengelasan tidak membutuhkan waktu lama, konstruksi ringan, kekuatan sambungan cukup baik, serta biaya relatif murah. Penerapan sambungan las sangat luas. Sambungan las banyak digunakan pada konstruksi jembatan, gedung, industri otomotif, industri peralatan rumah tangga, bahkan industri barang dengan bahan plastikpun banyak menggunakan proses las tersebut, (Gambar 4).

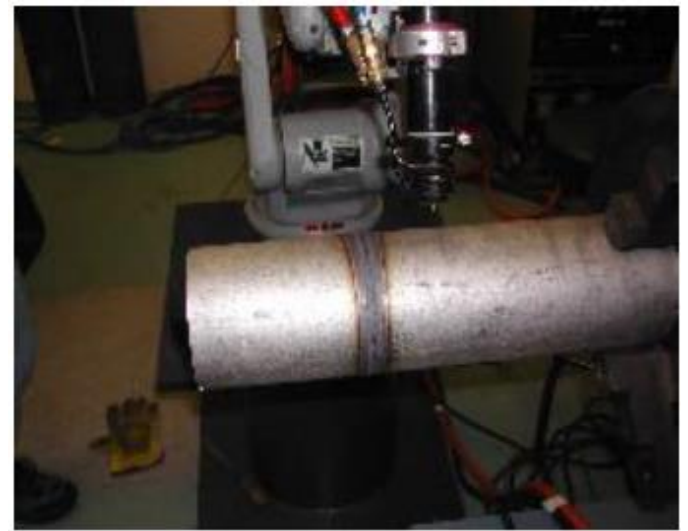

Gambar 4. Sambungan Las pada Pipa

\section{Klasifikasi Bentuk Sambungan Las}

Ada beberapa bentuk dasar sambungan las yang biasa dilakukan dalam penyambungan logam, bentuk tersebut adalah butt joint, fillet joint, lap joint edge joint, dan out-side corner joint (Gambar 5).

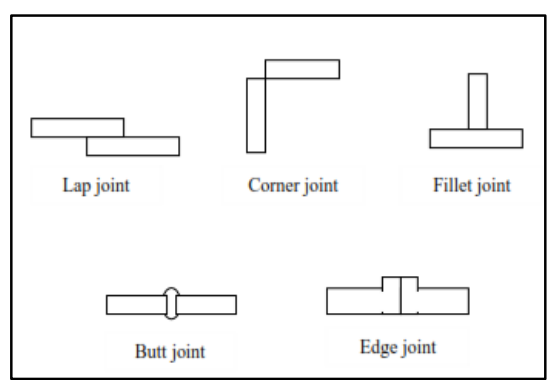

Gambar 5. Berbagai Bentuk Sambungan Las

\section{Korosi}

Korosi adalah reaksi redoks antara suatu logam dengan berbagai zat di lingkungannya yang menghasilkan senyawa-senyawa yang tak dikehendaki. Dalam bahasa sehari-hari, korosi disebut perkaratan. Pada peristiwa korosi, logam mengalami oksidasi, sedangkan oksigen (udara) mengalami reduksi. Karat logam umumnya adalah berupa oksida dan karbonat. Rumus kimia karat besi adalah $\mathrm{Fe}_{2} \mathrm{O}_{3}$. $\mathrm{xH}_{2} \mathrm{O}$, suatu zat padat yang berwarna coklat-merah. Korosi merupakan proses elektrokimia. Pada korosi besi, bagian tertentu dari besi itu berlaku sebagai anode, di mana besi mengalami oksidasi [3].

$\mathrm{Fe}(\mathrm{s}) \leftrightarrow \mathrm{Fe} 2+(\mathrm{aq})+2 \mathrm{e} \mathrm{E}^{\mathrm{o}}=+0.44 \mathrm{~V}$

Elektron yang dibebaskan di anode mengalir ke bagian lain besi itu yang bertindak sebagai katode, di mana oksigen tereduksi.

$$
\begin{aligned}
\mathrm{O}_{2}(\mathrm{~g})+2 \mathrm{H}_{2} \mathrm{O}(\mathrm{l})+4 \mathrm{e} \leftrightarrow & 4 \mathrm{OH}-(\mathrm{aq}) \mathrm{E}^{\mathrm{o}}=+0.40 \mathrm{~V} \\
& \text { Atau }
\end{aligned}
$$$$
\mathrm{O}_{2}(\mathrm{~g})+4 \mathrm{H}+(\mathrm{aq})+4 \mathrm{e} \leftrightarrow 2 \mathrm{H}_{2} \mathrm{O}(\mathrm{l}) \mathrm{E}^{\mathrm{o}}=+1.23 \mathrm{~V}
$$

Ion besi (II) yang terbentuk pada anode selanjutnya teroksidasi membentuk ion besi (III) yang kemudian membentuk senyawa oksida terhidrasi, $\mathrm{Fe}_{2} \mathrm{O}_{3}$. x $\mathrm{H} 2 \mathrm{O}$, yaitu karat besi. Mengenai bagian mana dari besi itu yang bertindak sebagai anode dan bagian mana yang bertindak sebagai katode, bergantung pada berbagai faktor, misalnya zat pengotor, atau perbedaan rapatan logam itu. Faktor-faktor yang menyebabkan korosi besi adalah kontak oksigen dan air.

Besi adalah logam yang paling banyak dan paling beragam penggunaannya. Salah satu kelemahan besi adalah mudah mengalami korosi. Korosi menimbulkan banyak kerugian karena mengurangi umur pakai berbagai barang atau bangunan yang menggunakan besi atau baja. Sebenarnya korosi dapat dicegah dengan mengubah besi menjadi baja tahan karat (stainless steel), akan tetapi proses ini terlalu mahal untuk kebanyakan penggunaan besi. Cara-cara pencegahan korosi besi, yaitu :

a) Pengecatan. Jembatan, pagar dan railing biasanya dicat. Cat menghindarkan kontak dengan udara dan air.

b) Pelumuran dengan Oli atau Gemuk.

c) Pembalutan dengan Plastik.

d) Tin Plating (pelapisan dengan timah).

e) Galvanisasi (pelapisan dengan zink).

f) Chromium Plating (pelapisan dengan kromium). 
g) Sacrificial Protection (pengorbanan anode).

Aluminium, zink, dan juga kromium, merupakan logam yang lebih aktif daripada besi. Jika demikian, mengapa logam-logam ini lebih awet? Sebenarnya, aluminium berkarat dengan cepat membentuk oksida aluminium $\left(\mathrm{Al}_{2} \mathrm{O}_{3}\right)$. Akan tetapi, perkaratan segera terhenti setelah lapisan tipis oksida terbentuk. Lapisan itu melekat kuat pada permukaan logam, sehingga melindungi logam di bawahnya terhadap perkaratan berlanjut. Lapisan oksida pada permukaan aluminium dapat dibuat lebih tebal melalui elektrolisis, proses yang disebut anodizing. Aluminium yang telah mengalami anodizing digunakan untuk membuat panci dan berbagai perkakas dapur, bingkai, kerangka bangunan (panel dinding), serta kusen pintu dan jendela. Lapisan oksida aluminium lebih mudah dicat dan memberi warna yang lebih terang.

\section{Perhitungan Laju Korosi}

Pengukuran laju korosi merupakan suatu hal yang penting dalam rekaya korosi. Permukaan material konstruksi di lingkungan korosif dilakukan berdasarkan data laju korosi. Korosi sangat dipengaruhi oleh lingkungan misalnya temperatur, $\mathrm{pH}$, oksigen, kecepatan fluida, dan zat-zat oksidator. Laju korosi juga bergantung pada konsentrasi reaktan, jumlah mulamula partikel (massa) logam, dan faktor mekanik seperti tegangan. Pengukuran laju korosi merupakan hal yang sangat penting di dalam proses rekayasa korosi. Permukaan material konstruksi di lingkungan korosif berdasarkan data laju korosi yang terjadi. Bila serangan korosi terjadi terhadap material logam secara merata, maka laju korosi dapat dihitung dengan metode kehilangan berat atau weight gain loss (WGL), pengujian ini sesuai dengan standar ASTM G 31-72. Laju korosi dinyatakan dalam mpy (milli inch per year). Dengan menghitung massa logam yang telah dibersihkan dari oksida dan massa tersebut dinyatakan sebagai massa awal lalu dilakukan pada suatu lingkungan yang korosif seperti pada air laut selama waktu tertentu. Setelah itu dilakukan penghitungan massa kembali dari suatu logam setelah dibersihkan logam tersebut dari hasil korosi yang terbentuk dan massa tersebut dinyatakan sebagai massa akhir. Dengan mengambil beberapa data seperti luas permukaan yang terendam, waktu perendaman dan massa jenis logam yang di uji maka dihasilkan suatu laju korosi.

Persamaan laju korosi dapat ditunjukkan pada persamaan berikut :

Corrosion Rate $=\frac{k \cdot w}{\rho \cdot A \cdot t}$

(mpy)

Keterangan :

$$
\begin{aligned}
& W=\text { kehilangan berat }(\mathrm{g}) \\
& \rho=\text { berat jenis }\left(\mathrm{g} / \mathrm{cm}^{3}\right) \\
& A=\text { luas sampel }\left(\mathrm{cm}^{2}\right) \\
& t=\text { waktu (jam) } \\
& k=\text { Konstanta }
\end{aligned}
$$

Tabel 1. Konstanta Perhitungan Laju Korosi Berdasarkan Satuannya

\begin{tabular}{|l|l|}
\hline Satuan Laju Korosi / Corrosion Rate & Konstanta \\
\hline Milli-inch per year $(\mathrm{mpy})$ & $3,45 \times 10^{6}$ \\
\hline Inches per year (ipy) & $3,45 \times 10^{3}$ \\
\hline Milimeters per year $(\mathrm{mm} / \mathrm{y})$ & $8,76 \times 10^{4}$ \\
\hline Micrometers per year $(\mu \mathrm{m} / \mathrm{y})$ & $8,76 \times 10^{7}$ \\
\hline
\end{tabular}

\section{Metode Penelitian}

Variabel Penelitian

1. Variabel Bebas : media pendingin udara, air, dan oli SAE 20.

2. Variabel Terikat : laju korosi.

3. Variabel Terkontrol : dimensi benda uji, kuat arus las listrik, dan lama pengujian korosi.

Waktu dan Tempat Penelitian Penelitian ini dilakukan pada Agustus-September 2016, di Laboratorium Teknik Mesin Kampus II Universitas Muhammadiyah Metro, Lampung.

Peralatan.

1. Mesin las busur listrik,

2. Adaptor,

3. Timbangan digital,

4. Gerinda,

5. Ampere meter, 
6. Vernier caliper,

7. Sikat kawat,

8. Wadah acrillyc,

9. Kabel,

10. Penjepit kabel (conector),

11. Isolasi,

12. Camera digital,

13. Peralatan safety welding (Kacamata las, sarung tangan las, sepatu safety, apron.

Bahan

1. Baja plat dengan ketebalan $10 \mathrm{~mm}$

2. Elektroda las

3. Oli SAE 20

4. Air

5. Larutan $\mathrm{HCl} 20 \%$

Bentuk dan dimensi spesimen las maupun spesimen uji korosi ditunjukkan pada gambar 6 dan 7 .

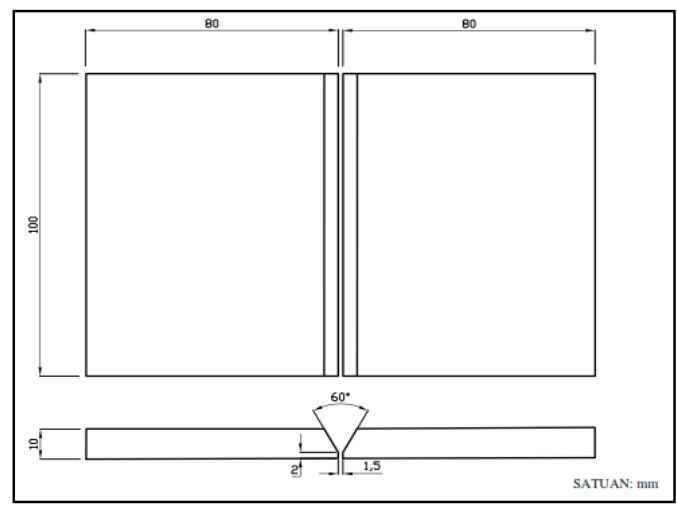

Gambar 6. Spesimen Las

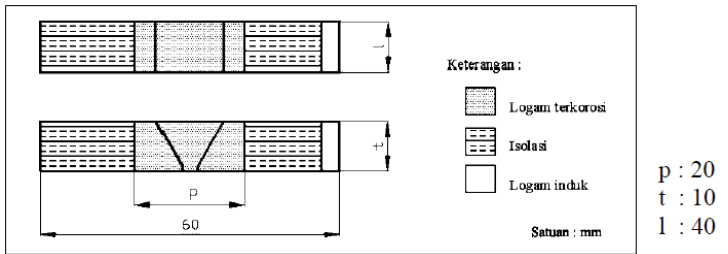

Gambar 7. Spesimen Uji Korosi

Prosedur Pengujian

1. Besi plat dipotong sesuai ukuran spesimen las sebanyak 9 pasang,

2. Melakukan penyambungan seluruh spesimen menggunakan las listrik

3. pasang spesimen didinginkan dengan udara, 3 pasang spesimen didinginkan dengan oli, dan 3 pasang spesimen didinginkan dengan air,

4. Spesimen dipotong sesuai dengan ukuran spesimen uji korosi,
5. Timbang dan ukur berat spesimen uji korosi,

6. Spesimen uji korosi dibungkus dengan isolasi kecuali pada sambungan / kampuh las,

7. Lakukan uji korosi selama 8 jam,

8. Keringkan dan lepas isolasi kemudian timbang spesimen untuk menghitung jumlah material terkorosi pada spesimen,

9. Skema pengujian korosi dapat dilihat pada gambar 8 .

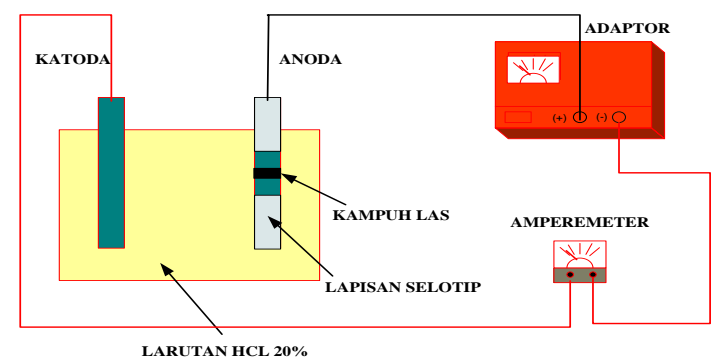

Gambar 8. Skema Pengujian Korosi

\section{Hasil dan Pembahasan}

\section{Data Pengujian Laju Korosi}

Korosi didefinisikan sebagai proses degradasi material akibat interaksi dengan lingkungan sekitarnya. Interaksi tersebut menimbulkan reaksi korosi yang umumnya merupakan reaksi elektrokimia. Empat faktor yang mempengaruhi dan berperan dalam reaksi elektrokimia yang bisa mengakibatkan korosi, antara lain yaitu: Anode, Katoda, Larutan elektrolit dan penghantar. Pengujian korosi dilakukan dengan mengalirkan arus listrik pada Anode dan Katode yang terilustrasikan pada gambar 14 dengan Anoda adalah sebagai spesimen uji korosi. Setelah melakukan pengujian maka dikumpulkan data-data yang diperoleh dari hasil pengujian korosi hasil pengelasan baja AISI 1045 dengan menvariasikan media pendinginan yaitu pendinginan menggunakan media air, oli, dan udara.

Sebelum dilakukan pengujian korosi, spesimen uji korosi terlebih dahulu ditimbang untuk mengetahui berat awal dari spesimen sebelum mengalami korosi. Kemudian pada setiap 2 jam sekali spesimen uji korosi dikeringkan dan 
kemudian timbang spesimen untuk menghitung jumlah material terkorosi pada spesimen. Pengujian korosi dilakukan selama akumulasi waktu 8 jam. Spesimen uji korosi berjumlah 9 spesimen dengan 3 spesimen pada setiap media pendingin yang ditunjukkan pada tabel 2 .

Tabel 2. Data spesimen uji korosi.

\begin{tabular}{|l|l|l|}
\hline No & Nomor spesimen & Media pendingin \\
\hline 1 & Spesimen 1 & Air \\
\hline 2 & Spesimen 2 & Air \\
\hline 3 & Spesimen 3 & Air \\
\hline 4 & Spesimen 4 & Oli \\
\hline 5 & Spesimen 5 & Oli \\
\hline 6 & Spesimen 6 & Oli \\
\hline 7 & Spesimen 7 & Udara \\
\hline 8 & Spesimen 8 & Udara \\
\hline 9 & Spesimen 9 & Udara \\
\hline
\end{tabular}

Data hasil pengujian korosi pengelasan baja AISI 1045 menggunakan media air sebagai media pendingin ditunjukkan pada tabel 3 .

Tabel 3. Data hasil pengujian korosi pada media pendingin air.

\begin{tabular}{|l|l|l|l|}
\hline Spesimen & $\begin{array}{l}\text { Berat awal } \\
(\mathrm{g})\end{array}$ & $\begin{array}{l}\text { Berat akhir } \\
(\mathrm{g})\end{array}$ & $\begin{array}{l}\text { Weight loss } \\
(\mathrm{g})\end{array}$ \\
\hline 1 & 188.8 & 177.8 & 1.52 \\
\hline 2 & 187.9 & 186.27 & 1.63 \\
\hline 3 & 188.2 & 186.87 & 1.33 \\
\hline Rata-rata & 1.493333 \\
\hline
\end{tabular}

Data hasil pengujian korosi pengelasan baja AISI 1045 menggunakan media oli sebagai media pendingin ditunjukkan pada tabel 4 .

Tabel 4. Data hasil pengujian korosi pada media pendingin oli.

\begin{tabular}{|l|l|l|ll|}
\hline Spesimen & $\begin{array}{l}\text { Berat awal } \\
(\mathrm{g})\end{array}$ & $\begin{array}{l}\text { Berat akhir } \\
(\mathrm{g})\end{array}$ & $\begin{array}{l}\text { Weight loss } \\
(\mathrm{g})\end{array}$ \\
\hline 4 & 189 & 187.02 & 1.98 & \\
\hline 5 & 188.3 & 186.32 & 2.01 & \\
\hline 6 & 188.8 & 186.8 & 2 \\
\hline \multicolumn{4}{|l|}{ Rata-rata } & 1.996667 \\
\hline
\end{tabular}

Data hasil pengujian korosi pengelasan baja AISI 1045 menggunakan media udara sebagai media pendingin ditunjukkan pada tabel 5 .

Tabel 5. Data hasil pengujian korosi pada media pendingin udara.

\begin{tabular}{|c|c|c|c|}
\hline Spesimen & Berat awal & Berat akhir & $\begin{array}{l}\text { Weight loss } \\
(\mathrm{g})\end{array}$ \\
\hline 7 & 187.6 & 182.8 & 4.8 \\
\hline 8 & 188.6 & 184.1 & 4.5 \\
\hline 9 & 188.5 & 184 & 4.5 \\
\hline \multicolumn{3}{|l|}{ Rata-rata } & 4.6 \\
\hline
\end{tabular}

Laju Korosi
Laju korosi dihitung dengan metode kehilangan berat (weight loss) dan laju korosi pada penelitian ini dinyatakan dengan satuan "mpy" (milli-inch per year).

Tabel 6. Data perhitungan rumus laju korosi

\begin{tabular}{|l|l|l|l|}
\hline & $\begin{array}{l}\text { Pengelasan } \\
\text { dengan } \\
\text { media } \\
\text { pendingin } \\
\text { air }\end{array}$ & $\begin{array}{l}\text { Pengelasan } \\
\text { dengan } \\
\text { media } \\
\text { pendingin } \\
\text { oli }\end{array}$ & $\begin{array}{l}\text { Pengelasan } \\
\text { dengan } \\
\text { media } \\
\text { pendingin } \\
\text { udara }\end{array}$ \\
\hline Density $(\rho)$ & $7.87 \mathrm{~g} / \mathrm{cm}^{3}$ & $7.87 \mathrm{~g} / \mathrm{cm}^{3}$ & $7.87 \mathrm{~g} / \mathrm{cm}^{3}$ \\
\hline $\begin{array}{l}\text { Weight } \\
\text { loss } \\
\text { everage } \\
(W)\end{array}$ & $1.493333 \mathrm{~g}$ & $1.996667 \mathrm{~g}$ & $4.6 \mathrm{~g}$ \\
\hline $\begin{array}{l}\text { Konstanta } \\
(k)\end{array}$ & $3.45 \times 10^{6}$ & $3.45 \times 10^{6}$ & $3.45 \times 10^{6}$ \\
\hline $\begin{array}{l}\text { Luas area } \\
\text { korosi }(A)\end{array}$ & $8 \mathrm{~cm}^{2}$ & $8 \mathrm{~cm}^{2}$ & $8 \mathrm{~cm}^{2}$ \\
\hline Waktu $(t)$ & $8 \mathrm{jam}^{2}$ & $8 \mathrm{jam}^{2}$ & $8 \mathrm{jam}$ \\
\hline
\end{tabular}

Dari data yang tertulis di tabel 8 , laju korosi dapat dihitung dengan rumus Corrosion Rate $=\frac{k \cdot w}{\rho \cdot A \cdot t} \quad$ (mpy)

Sehingga didapatkan nilai laju korosi untuk pengelasan dengan media pendingin air adalah :

$$
\begin{aligned}
& \text { Corrosion Rate }(\text { mpy })=\frac{3.45 \times 10^{6} .1 .493333}{7.87 .8 .8} \\
& =\quad 10228.71 \quad \mathrm{mpy} \\
& =\quad 10.22871 \mathrm{inch} / \text { tahun }
\end{aligned}
$$

Nilai laju korosi untuk pengelasan dengan media pendingin oli adalah :

$\begin{array}{ccl}\text { Corrosion Rate }(\text { mpy })= & \frac{3.45 \times 10^{6} \cdot 1.996667}{7.87 .8 .8} \\ = & 13676.34 & \text { mpy } \\ = & 13.67634 & \text { inch/tahun }\end{array}$

Nilai laju korosi untuk pengelasan dengan media pendingin udara adalah :

$$
\begin{aligned}
\text { Corrosion Rate }(\text { mpy }) & =\frac{3.45 \times 10^{6} \cdot 4.6}{7.87 .8 .8} \\
& =31508.1 \mathrm{mpy} \\
& =31.5081 \mathrm{inch} / \mathrm{tahun}
\end{aligned}
$$

\section{Pembahasan}

Dari perhitungan didapatkan nilai laju korosi untuk pengelasan dengan media pendingin air adalah 10228.71 mpy atau 10.22871 inch/tahun. Nilai laju korosi untuk pengelasan dengan media pendingin oli adalah 13676.34 mpy atau 13.67634 inch/tahun. Nilai laju korosi untuk pengelasan dengan media pendingin udara 
31508.1 mpy atau 31.5081 inch/tahun. Nilai tersebut dapat dinterprestasikan dalam sebuah grafik seperti pada gambar 9 .

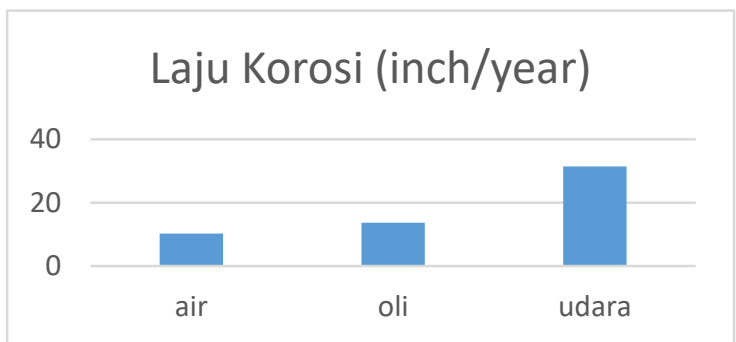

Gambar 9. Grafik laju korosi pengelasan baja dari beberapa media pendingin

Dari nilai perhitungan laju korosi dan gambar grafik tersebut di atas menunjukkan bahwa nilai laju korosi paling tinggi adalah pengelasan dengan media pendingin udara yaitu senilai $31508.1 \mathrm{mpy}$ atau 31.5081 inch/tahun, nilai laju korosi terendah adalah pengelasan dengan media pendingin air yaitu $10228.71 \mathrm{mpy}$ atau 10.22871 inch/tahun. Hal ini mengindikasikan bahwa PWHT (post welding heat threatment) memiliki pengaruh besar dalam usaha penghambatan laju korosi. Apabila laju korosi dapat dihambat, tentu akan dapat meningkatkan kualitas sebuah produk terutama dalam bidang manufaktur logam.

\section{Kesimpulan}

1. Nilai laju korosi paling tinggi adalah pengelasan dengan media pendingin udara yaitu senilai $31508.1 \mathrm{mpy}$ atau $31.5081 \mathrm{inch} / \mathrm{tahun}$, nilai laju korosi terendah adalah pengelasan dengan media pendingin air yaitu 10228.71 mpy atau 10.22871 inch/tahun.

2. PWHT (post welding heat threatment) memiliki pengaruh besar dalam usaha penghambatan laju korosi.

\section{Daftar Pustaka}

[1]. Groover, Mikell P. 1996. Fundamentals of modern manufacturing: materials, processes, and systems. Upper Saddle River, N.J.: Prentice Hall.
[2]. Graham E. (1990). Maintenance Welding, Prentice-Hall Inc: New Jersey.

[3]. Fontana, Mars. G.,1978, Corrosion Engineering, McGraw-Hill, Inc.

[4]. Harrison, P.L., Farrar, P.L., 1989, "Aplication of Continuous Cooling Transformation Diagrams for Welding of Steel", International Materials Reviews. Vol 34, No. 1, 35-51.

[5]. ASM Handbook Comitte, 1995, "Metal Handbook, Volume 6: Welding, Brasing and Soldering", Edisi 3, American Society for Metal International, New York. 